\title{
USE OF GROWTH RETARDANTS IN WHEAT ${ }^{1}$
}

\author{
Utilização de Redutores de Crescimento em Trigo
}

\author{
ESPINDULA, M.C. ${ }^{2}$, ROCHA, V.S. ${ }^{3}$, GROSSI, J.A.S. ${ }^{3}$, SOUZA, M.A. ${ }^{3}$, SOUZA, L.T. ${ }^{2}$ and \\ FAVARATO, L.F. ${ }^{4}$
}

\begin{abstract}
In general, lodging has been controlled by restricting nitrogen fertilizer application and/or using short cultivars. Growth retardants can also be used to solve this problem.The objective of this study was to evaluate the effect of rates and application times of three growth retardants on Pioneiro wheat cultivar. The trial was carried out in Viçosa-MG, from May to September 2005, in a factorial and hierarchical scheme, in a randomized block design with four replications and a control treatment. The treatments consisted of 500, 1,000 and 1,500 $\mathrm{g} \mathrm{ha}^{-1}$ of chlormequat; $62.5,125$ and $187.5 \mathrm{~g} \mathrm{ha}^{-1}$ of trinexapacethyl and 40, 80 and $120 \mathrm{~g} \mathrm{ha}^{-1}$ of paclobutrazol applied at growth stages 6 or 8 , growth stage used on the scale of Feeks and Large, and a control treatment without growth retardant application. Only trinexapac-ethyl and chlormequat were efficient in reducing plant height; the effect of chlormequat and paclobutrazol on plant height was independent of the application time, but the trinexapac-ethyl at growth stage 8 produced shorter plant height than at stage 6. Increasing growth retardant rates produced shorter plant heights; chlormequat and paclobutrazol did not affect grain yield. However, the highest trinexapac-ethyl rates reduced wheat yield.
\end{abstract}

Keywords: chlormequat, trinexapac-ethyl, paclobutrazol, Triticum aestivum, plant height, yield

\begin{abstract}
RESUMO - De modo geral, o acamamento tem sido controlado mediante restrição da aplicação de fertilizantes nitrogenados e/ou o uso de cultivares de porte baixo. No entanto, esse problema também pode ser solucionado pela utilização de redutores de crescimento. Objetivou-se com este trabalho avaliar o efeito de doses e épocas de aplicação de três redutores de crescimento sobre plantas de trigo do cultivar Pioneiro. O experimento, conduzido em Viçosa-MG de maio a setembro de 2005, foi instalado com os tratamentos dispostos em esquema fatorial e hierárquico com uma testemunha, no delineamento de blocos casualizados com quatro repetições. Os tratamentos foram: 500, 1.000 e $1.500 \mathrm{~g} \mathrm{ha}^{-1}$ de clormequat; 62, 5, 125 e 187, $5 \mathrm{~g} \mathrm{ha}^{-1}$ de trinexapac-etil; e 40, 80 e $120 \mathrm{~g} \mathrm{ha}^{-1}$ de paclobutrazol, aplicados no estádio 6 ou 8 da escala Feeks e Large, mais uma testemunha sem aplicação de redutor. O trinexapac-etil e o clormequat foram mais eficientes em reduzir a estatura das plantas de trigo. A ação do clormequat e do paclobutrazol sobre a altura das plantas foi independente da época de aplicação, porém o trinexapac-etil no estádio 8 promoveu menor altura do que no estádio 6. O aumento das doses dos redutores promoveu menor estatura das plantas; clormequat e paclobutrazol não afetaram a produtividade dos grãos. A maior dose de trinexapac-etil causou redução na produtividade do trigo.
\end{abstract}

Palavras-chave: clormequat, trinexapac-etil, paclobutrazol, Triticum aestivum, altura de plantas, produtividade.

Recebido para publicação em 10.3.2008 e na forma revisada em 5.6.2009.

2 Doutorando em Fitotecnia, Dep. de Fitotecnia da Universidade Federal de Viçosa - DFT/UFV, Av. P. H. Rolfs, s/noe, 36570-000 Viçosa--MG, <curitibaespindula@yahoo.com.br, souzalts@yahoo.com.br.>; ${ }^{3}$ Professor, Dep. de Fitotecnia -DFT/UFV, <vsrocha@ufv.br, jgrossi@ufv.br, moacil@ufv.br>; ${ }^{4}$ Graduando em Agronomia da UFV/DFT, <luiz4x4@yahoo.com.br>.

Planta Daninha, Viçosa-MG, v. 27, n. 2, p. 379-387, 2009 


\section{INTRODUCTION}

Lodging in cereals refers to the displacement of the stem from its vertical position and leaning towards the soil. Stem lodging is usually caused by the weight of water accumulated in the mature ears, wind, and low stem resistance, among other factors (Taiz \& Zeiger, 2004). In cereals and other annual grain crops, this phenomenon is a serious problem (Stachecki et al., 2004) since, among other consequences, it hinders the mechanical grain harvest process (Taiz \& Zeiger, 2004). In general, lodging has been controlled by restricting nitrogen fertilizer application and/or using short cultivars (Rodrigues et al., 2003). Growth retardants can also be used to solve this problem.

Growth retardants are natural or synthetic chemical substances that can be directly applied on plants to alter structural or vital processes by modifying hormone balance to increase yield, improve quality or facilitate harvesting (Lamas, 2001; Mateus et al., 2004).

Growth retardants act as chemical signalers in the regulation of plant growth and development. They usually bind to receivers in the plant and start a series of cell changes that can affect the initiation or modification of organ or tissue development. Plant height retardants are usually antagonistic to gibberellins and act by modifying their metabolism (Rodrigues et al., 2003) and for this reason they are frequently called antigibberellins.

Inhibitors of gibberellin synthesis are divided in three classes, and each specific class interrupts one of the three stages of gibberellin synthesis. The first class of compounds, such as quartenary ammonium (chlormequat chloride or CCC, mepiquat chloride and AMO-1618) and phosphonium (chlorophenium chloride), block the ent-kaurene synthesis from geranylgeranyl diphosphate. AMO-1618 and CCC specifically inhibits the activity of copalyl diphosphate synthase and, in smaller degree, of ent-kaurene synthase. The second class consists of heterocyclic compounds containing nitrogen, such as ancymidol (a pyrimidine), tetcyclases (a norbornanodiazetine), and triazole type compounds (paclobutrazol and uniconazole).
These compounds inhibit the oxidation of ent-kaurene to ent-kaurenoic acid by the P450 monooxygenases during stage 2 of gibberellin biosynthesis. The third group includes acylcyclohexanediones that inhibit 2-oxoglutarate-dependent dioxygenases at stage 3 of gibberellin biosynthesis. Acylcyclohexanediones, such as prohexadione$\mathrm{Ca}$ and trinexapac-ethyl (a salt and an ester, respectively), have structures similar to 2oxoglutarate and, therefore, inhibit the dioxygenase activity by competing for the biding site of the cosubstrate 2-oxoglutarate (Srivastava, 2002).

Inhibiting products of gibberellin are used commercially to prevent lodging in some plants. In wheat, studies with chlormequat (Rodrigues et al., 2003; Stachecki et al., 2004), trinexapac-ethyl (Zagonel et al., 2002a, b; Matysiak, 2006; Zagonel \& Fernanndes, 2007) and paclobutrazol (Guoping, 1997; Hajihashemi et al., 2007) presented good results in reducing plant stature. However, the product to be used as well as dose and application times vary with the cultivar and the culture. For this reason, this work aimed to evaluate the effect of rates and application times of three growth retardants on Pioneiro wheat cultivar.

\section{MATERIAL AND METHODS}

The trial was carried at the Experimental Station Prof. Diogo Alves de Mello, at the Universidade Federal de Viçosa, in Viçosa-MG ( $20^{\circ} 45^{\prime} \mathrm{S} ; 42^{\circ} 51^{\prime} \mathrm{W}$; $650 \mathrm{~m}$ altitude), from May to September, 2005. Daily data of the temperature (maximum, average and minimum), pluvial precipitation and air relative humidity mean throughout the experiment were provided by the climatologic station of the Department of Agricultural Engineering of the university (Figure 1).

The trial was established in an area that had been cultivated over the last years with soybean (summer) and wheat (winter). The soil of the experimental area is classified as RedYellow Argisol (Terrace Phase) (Embrapa, 2006). Soil chemical analysis of the $0-0.20 \mathrm{~m}$ layer showed the following characteristics: $\mathrm{pH}=5.6 ; \mathrm{P}=11.47 \mathrm{mg} \mathrm{dm}^{-3} ; \mathrm{K}^{+}=115 \mathrm{mg} \mathrm{dm}^{-3}$; $\mathrm{Ca}^{2+}=1.89 \mathrm{cmol}_{\mathrm{c}} \mathrm{dm}^{-3} ; \mathrm{Mg}^{2+}=0.28 \mathrm{cmol}_{\mathrm{c}} \mathrm{dm}^{-3}$; 
$\mathrm{Al}^{3+}=0 \mathrm{cmol}_{c} \mathrm{dm}^{-3} ; \mathrm{H}^{+}+\mathrm{Al}^{3+}=3.11 \mathrm{cmol}_{\mathrm{c}} \mathrm{dm}^{-3}$; base saturation $(\mathrm{V})=44 \%$ and organic matter $(\mathrm{OM})=1.5 \mathrm{dag}_{\mathrm{kg}}{ }^{-1}$.

Soil preparation operations consisted of plowing followed by two disk harrowing and basic fertilization of $250 \mathrm{~kg} \mathrm{ha}^{-1}$ with NPK 8-28-16. Pioneer wheat cultivar, characterized by medium height and moderate resistance to lodging (Embrapa, 2005), was sown using a plot sowing machine on May 17, 2005. Topdressing of ammonium sulfate was applied in the beginning of tillering ( 15 days after emergence) to provide $40 \mathrm{~kg} \mathrm{ha}^{-1}$ of $\mathrm{N}$. Harvesting was carried out on September 15, 2005.

The experiment was arranged in a factorial and hierarchical scheme, in a randomized block design with four replications and a control treatment. The treatments consisted of three growth retardants: 1) chlormequat (Cycocel) (2-chlorine-ethyl-trimethylammonium chloride); 2) trinexapac-ethyl (Moddus) (4cyclopropryl(hydroxy) me thylene-3, 5dioxocyclohexane ethyl carboxilate) and 3) paclobutrazol (Cultar) [(2RS, 3RS) 1-(4Chlorophenyl)-4,4-dimethyl-2-(1H-1,2,4triazole-1-yl) pentane-3-ol] applied at three rates (500, 1000 and $1500 \mathrm{~g} \mathrm{ha}^{-1}$ of chlormequat; 62.5, 125 and $187.5 \mathrm{~g} \mathrm{ha}^{-1}$ of trinexapac-ethyl and 40, 80 and $120 \mathrm{~g} \mathrm{ha}^{-1}$ of paclobutrazol) and two application times, the first at growth stage 6 in the scale of Feeks and Large with plants at floral differentiation with the first visible node, or at stage 8 of the same scale, with plants with the second node already shown, and a control treatment without retardant application.

Growth retardants were applied 24 or 34 days after plantlet emergence, corresponding to the $1^{\text {st }}$ and the $2^{\text {nd }}$ application times, respectively, using a $\mathrm{CO}_{2}$ backpack sprayer, at constant pressure of 2.5 bar inch $^{-2}$, with two XR 110-015 fan nozzles, $0.5 \mathrm{~m}$ spaced. A volume equivalent to $150 \mathrm{~L} \mathrm{ha}^{-1}$ of solution was applied.

Each experimental plot consisted of five $5 \mathrm{~m}$ long rows, spaced $0.184 \mathrm{~m}$ apart. The plot's useful area $\left(2.208 \mathrm{~m}^{2}\right)$ comprised the three central rows, discarding both half-meter ends. Sowing density was 350 useful seeds $\mathrm{m}^{-2}$.

Plant height was recorded for fifteen randomly selected plants per plot, from collar to ear apex, not including awns. The mass of
1,000 grains was determined by counting and weighing eight replications of 100 grains and extrapolating to 1,000 grains, as well as the hectoliter mass, using an appropriate scale, both with grains from plants in the useful area. Ear number $\mathrm{m}^{-2}$ was determined by direct count in one segment of 1 meter in each of the three central rows in the useful area, randomly selected. Grain number per ear, aerial part dry mass, and harvest index (grain yield/dry mass of aerial part ratio) were determined from 100 plants, sequentially harvested in the central row of the plot. Grain yield (corrected to $13 \%$ moisture) was determined in grains from plants in the useful area and expressed to $\mathrm{kg} \mathrm{ha}^{-1}$.

Data were examined by analysis of variance and the means were compared by the Tukey test, at 5\% level. Regression analysis was used to compare rates and the mathematical models were chosen according to the best fitting equations and confirmed by the largest coefficients of determination $\left(\mathrm{r}^{2} /\right.$ $\mathrm{R}^{2}$ ), significance of the regression coefficients $\left(\beta_{\mathrm{i}}\right)$ and the regression's $\mathrm{F}$ test, both at $5 \%$ level, as well as by the biological phenomenon. The significance of the regression coefficients $\left(\beta_{\mathrm{i}}\right)$ was shown in the equation, admitting * and ** as significant at 5 and $1 \%$, respectively.

\section{RESULTS AND DISCUSSION}

The nitrogen dose used, as well as the absence of strong rain in the end of the grain filling (Figure 1), did not favor the occurrence of lodging in any of the treatments. However, this phenomenon can occur in this cultivar when submitted to high doses of the same $\mathrm{N}$ or to a dose similar to that used in this work (result not published), if the climatic conditions are favorable.

The application times had no effect on plant height for any rate of chlormequat and paclobutrazol (Table 1). On the other hand, for all the trinexapac-ethyl rates, plant height was shorter at the $2^{\text {nd }}$ time. Trinexapacethyl effects are mainly related with stalk elongation, since it had greater influence on the growth of this internode at the $2^{\text {nd }}$ time (results not shown). Zagonel \& Fernandes (2007), applying trinexapac-ethyl to the cultivars OR-1, CD-104 and CEP-24 at two 
different times, between the first and the second nodes and between the second and the third visible nodes, also presented found shorter height in plants receiving late application.

Trinexapac-ethyl produced the shortest plant height, chlormequat produced intermediate height and paclobutrazol the highest plant height at both application times (Table 1). The differences found between chlormequat and trinexapac-ethyl suggest greater effectiveness of the former in reducing wheat height. The lesser reduction of the stature for paclobutrazol, could be due to other factors such as low concentration of the product (Klein et al., 2002), forms of application (Tinoco, 2005) also for the studied cultivar, since it can respond differently to a different retardant (Duarte Filho et al., 2004). Thus, further studies are necessary in this area, on reducer interference.
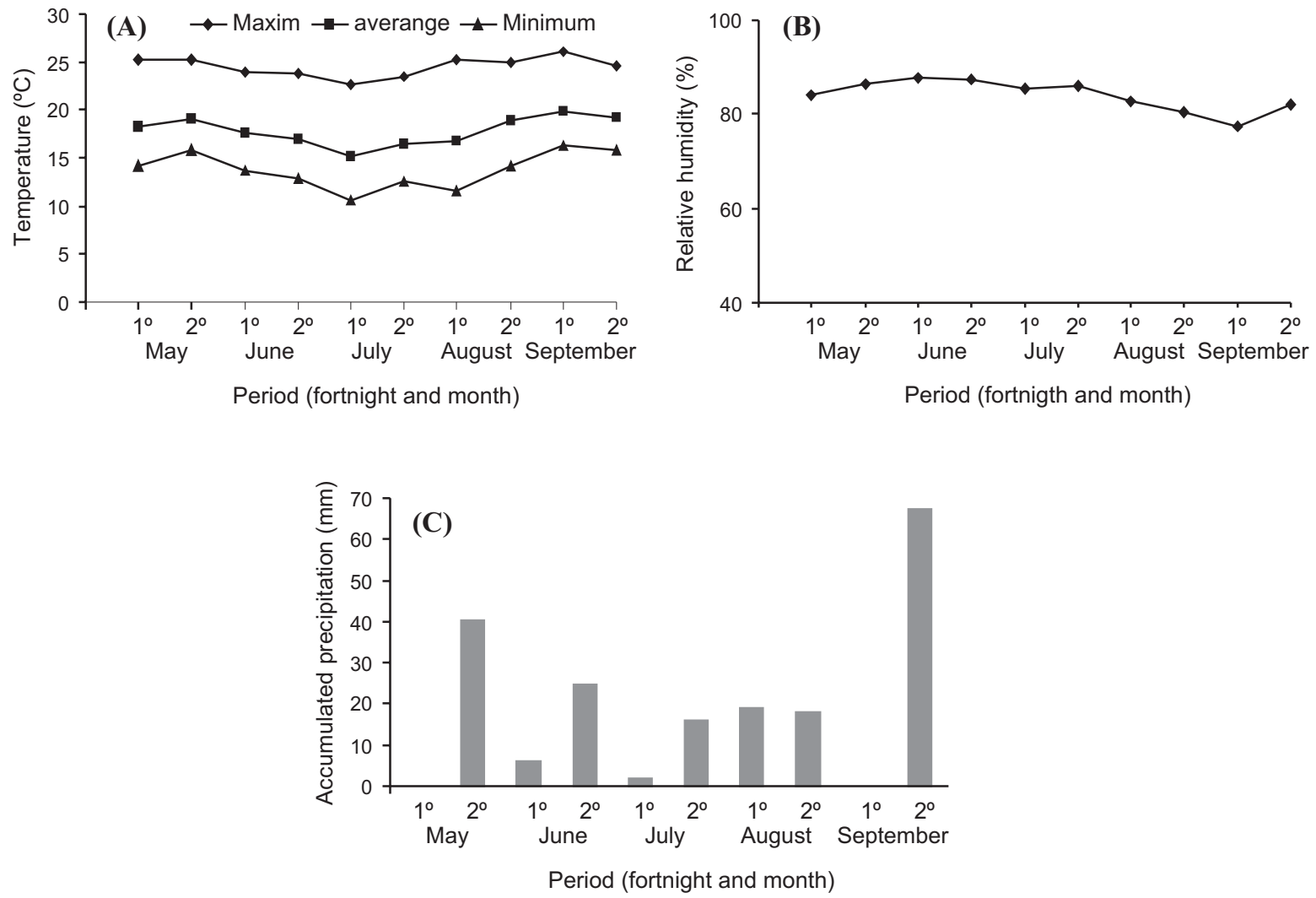

Figure 1 - Temperatures: maximum, average and minimum (A); Relative humidity (B); Accumulated precipitation (C), from May to September. Viçosa-MG, 2005.

Table 1 - Height $(\mathrm{cm})$ of wheat plants, Pioneiro cultivar, treated with rates of three growth retardants applied at Time $1=$ stage 6 , or Time $2=$ stage 8 of the Feeks and Large scale (24 and 34 days after emergence). Viçosa-MG, 2005

\begin{tabular}{|c|c|c|c|c|c|c|c|c|c|}
\hline & \multicolumn{3}{|c|}{ Chlormequat } & \multicolumn{3}{|c|}{ Trinexapac-ethyl } & \multicolumn{3}{|c|}{ Paclobutrazol } \\
\hline & $500^{\frac{1}{}}$ & 1,000 & 1,500 & 62.5 & 125 & 187.5 & 40 & 80 & 120 \\
\hline Time $1^{\underline{2} /}$ & $85.80 \mathrm{a}$ & $81.75 \mathrm{a}$ & $81.16 \mathrm{a}$ & $86.20 \mathrm{a}$ & $77.99 \mathrm{a}$ & $64.57 \mathrm{a}$ & $90.61 \mathrm{a}$ & $89.19 \mathrm{a}$ & $88.06 \mathrm{a}$ \\
\hline Time 2 & $83.49 \mathrm{a}$ & $81.87 \mathrm{a}$ & $80.49 \mathrm{a}$ & $81.08 \mathrm{~b}$ & $68.26 \mathrm{~b}$ & $61.67 \mathrm{~b}$ & $91.34 \mathrm{a}$ & $90.14 \mathrm{a}$ & $89.73 \mathrm{a}$ \\
\hline Time $1^{3 /}$ & \multicolumn{3}{|c|}{$82.90 \mathrm{Ba}$} & \multicolumn{3}{|c|}{$76.25 \mathrm{Ca}$} & \multicolumn{3}{|c|}{$89.29 \mathrm{Aa}$} \\
\hline Time 2 & \multicolumn{3}{|c|}{$81.95 \mathrm{Ba}$} & \multicolumn{3}{|c|}{$70.33 \mathrm{Cb}$} & \multicolumn{3}{|c|}{$90.41 \mathrm{Aa}$} \\
\hline $\mathrm{CV}(\%)$ & \multicolumn{9}{|c|}{10.77} \\
\hline
\end{tabular}

${ }^{1 /}$ Rate in $\mathrm{g} \mathrm{ha}^{-1} .{ }^{2 /}$ Unfolding of the interaction (time $\mathrm{x}$ rate)/retardant. ${ }^{3 /}$ Unfolding of the interaction time $\mathrm{x}$ retardant. Means followed by the same small letter in the column and capital letter in the row are not significantly different by the Tukey test, at $5 \%$ probability. 
There was negative a linear rate effect on plant height for all retardants at both times (Figure 2). Height reduction as a function of chlormequat rates was also reported for cotton (Lamas et al., 2000; Furlani Júnior et al., 2003).
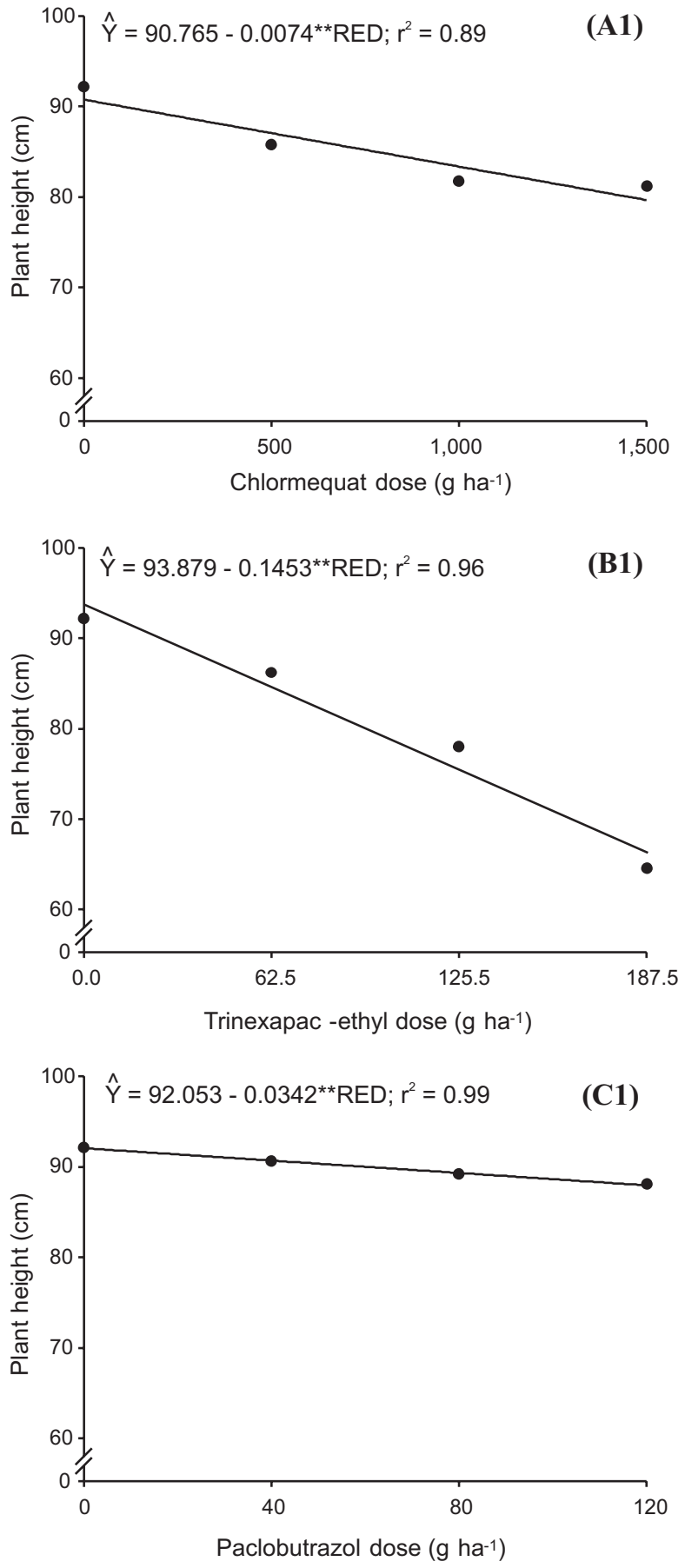

Zagonel \& Fernandes (2007) found linear height decrease in wheat plants with trinexapac-ethyl in seven of the eight studied cultivars. The results found for both growth retardants indicate their efficiency in reducing plant height.
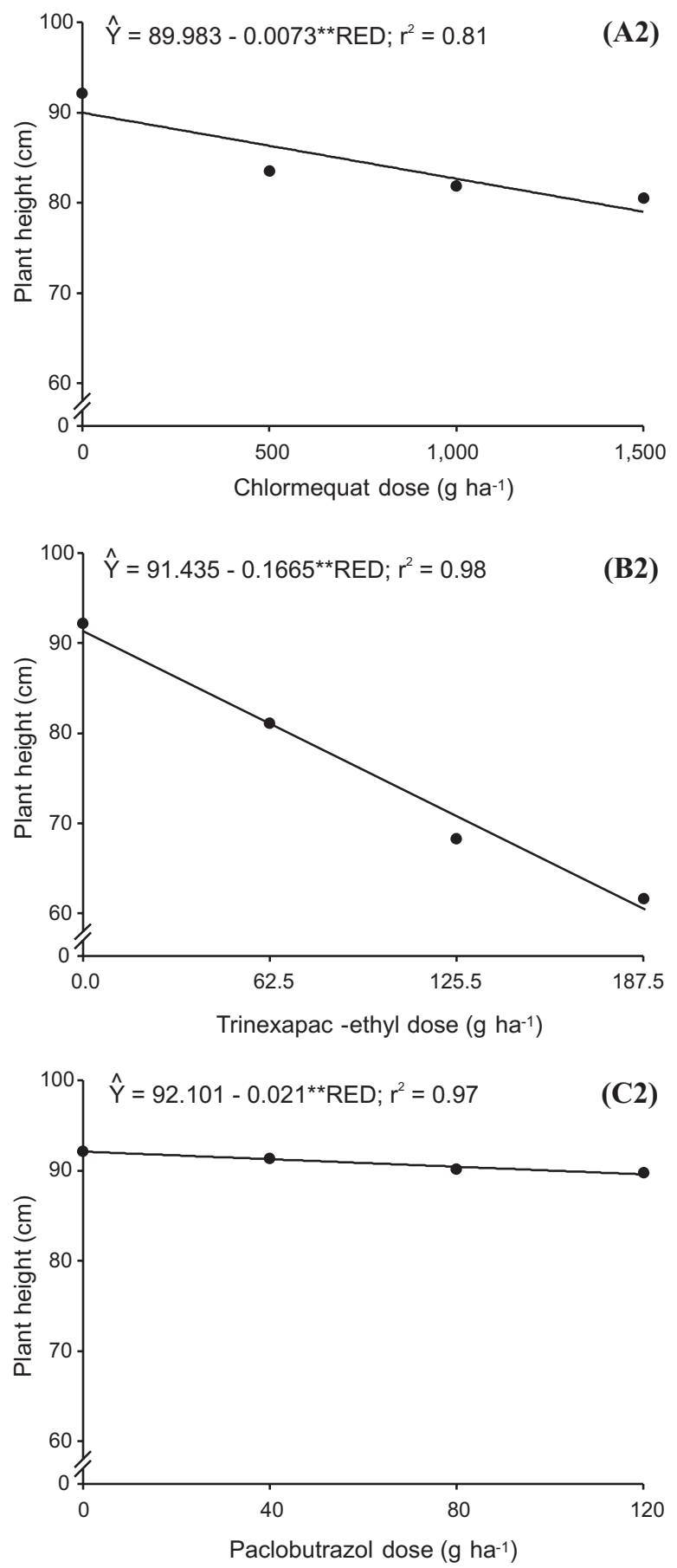

Figure 2 - Plant height of Pioneiro wheat cultivar treated with chlormequat at stage 6 (A1) or 8 (A2), trinexapac-ethyl, at stage 6 (B1) or 8 (B2), and paclobutrazol at stage $6(\mathrm{C} 1)$, or $8(\mathrm{C} 2)$ of the Feeks and Large scale. CV (\%)=10.77. Viçosa-MG, 2005. 
Increasing paclobutrazol rates also caused reductions in plant height for geranium treated with $0,5,10$ and $20 \mathrm{mg} \mathrm{dm}^{-3}$ (Tinoco, 2005) and wheat with 0 or $30 \mathrm{mg} \mathrm{dm}^{-3}$ of the growth retardant (Hajihashemi et al., 2007). However, in the present work, the reductions were less pronounced, since the paclobutrazol molecule is not widely mobile in the plant, and consequently, when it is sprayed over the plants, only the portion absorbed by the stem is effectively translocated into the xylem (Styer, 2003). Besides, the rates may have been insufficient for effective reductions. As mentioned before, further studies are needed to clarify the effects of paclobutrazol.

Hectolitre mass of the grains was similar among the growth retardants at both application times. Hectolitre mass coming from plants treated with trinexapac-ethyl at Time 1 was higher than at Time 2 (Table 2). This may have been caused by the impaired grain filling the resulted from the smaller photosynthetic area of the plants.

The treatment with paclobutrazol gave greater thousand-grain mass and greater dry mass of the aerial part than chlormequat and trinexapac-ethyl, without differences between the last two growth retardants (Table 2). Buzetti et al. (2006) and Stachecki et al. (2004) found no chlormequat effects on thousand-grain mass of rice and wheat, respectively. Despite this result, it is suggested that the impairment of grain filling with paclobutrazol could be the result of a lower photosynthetic capacity caused by a smaller leaf area, being confirmed by the lowest dry mass of the aerial part (Table 2), which can also explain the trinexapac-ethyl effects. Matysiak (2006) found no significant effects of trinexapac-ethyl on wheat cultivar Korweta, in Poland, whereas Zagonel et al. $(2002 \mathrm{a}, \mathrm{b})$ reported reductions in the grain mass of cultivars IAPAR-53 and OR- 1 with $125 \mathrm{~g} \mathrm{ha}^{-1}$ of trinexapac-ethyl, in comparison with the control without the retardant.

The highest plant dry mass found with paclobutrazol can be due to the lack of effect of this retardant, as discussed for plant height. The lowest dry mass of plants treated with chlormequat and trinexapac-ethyl confirms the aerial part reduction mainly height plant, caused by these growth retardants. Dry mass reduction is also associated with grain yield reduction in plants treated with trinexapacethyl.

The dry mass of the aerial part of the wheat plants decreased linearly with increasing rates of chlormequat and trinexapac-ethyl (Figure 3). Paclobutrazol rates had no effect on this trait. Reductions in dry mass caused by chlormequat and trinexapac-ethyl again reflect the inhibition effect on the vegetative growth of wheat. Tinoco (2005) also found reduction in the dry mass of the stem and leaves of geranium treated with chlormequat rates, and Freitas et al. (2002) found decreasing dry mass for Bahiagrass (Paspalum notatum Flugge) treated with different rates of trinexapac-ethyl. Again, the results found with paclobutrazol are not conclusive, since Tinoco (2005) found reduction in the dry mass of the stem and leaves of geranium treated with this retardant.

Table 2 - Hectolitre mass $\left(\mathrm{kg} \mathrm{hL}^{-1}\right)$, thousand-grain mass (g), dry mass of the aerial part $\left(\mathrm{kg} \mathrm{ha}^{-1}\right)$, grain yield $\left(\mathrm{kg} \mathrm{ha}^{-1}\right)$ and harvest index of Pioneiro wheat cultivar, treated with three growth retardants applied at Time $1=$ stage 6 or Time $2=$ stage 8 of the Feeks and Large scale (24 and 34 days after emergence). Viçosa-MG, 2005

\begin{tabular}{|l|c|c|c|c|c|c|c|}
\hline \multirow{3}{*}{ Retardant } & \multicolumn{9}{|c|}{ Characteristic } \\
\cline { 2 - 8 } & \multicolumn{2}{|c|}{ Hectolitre mass } & $\begin{array}{c}\text { Thousand grain } \\
\text { mass }\end{array}$ & $\begin{array}{c}\text { Dry mass of the } \\
\text { aerial part }\end{array}$ & Grain yield & \multicolumn{2}{c|}{ Harvest index } \\
\cline { 2 - 8 } & Time1 & Time 2 & --- & --- & --- & Time 1 & Time 2 \\
\hline Chlormequat & $79.72 \mathrm{Aa}$ & $80.02 \mathrm{Aa}$ & $37.09 \mathrm{~b}$ & $11,814.51 \mathrm{~b}$ & $5,493.82 \mathrm{a}$ & $0.485 \mathrm{Aa}$ & $0.493 \mathrm{Aa}$ \\
\hline Trinexapac-ethyl & $80.25 \mathrm{Aa}$ & $79.34 \mathrm{Ba}$ & $36.56 \mathrm{~b}$ & $11,796.67 \mathrm{~b}$ & $4,929.26 \mathrm{~b}$ & $0.490 \mathrm{Aa}$ & $0.472 \mathrm{Bb}$ \\
\hline Paclobutrazol & $80.10 \mathrm{Aa}$ & $80.06 \mathrm{Aa}$ & $38.35 \mathrm{a}$ & $12,464.46 \mathrm{a}$ & $5,379.52 \mathrm{a}$ & $0.478 \mathrm{Aa}$ & $0.487 \mathrm{Aa}$ \\
\hline CV (\%) & \multicolumn{2}{|c|}{1.06} & 4.31 & 8.12 & 8.07 & 3.80 & \\
\hline
\end{tabular}

Means, for the same trait, followed by the same capital letter in the row and small letter in the column are not significantly different by the Tukey test, at $5 \%$ of probability. 

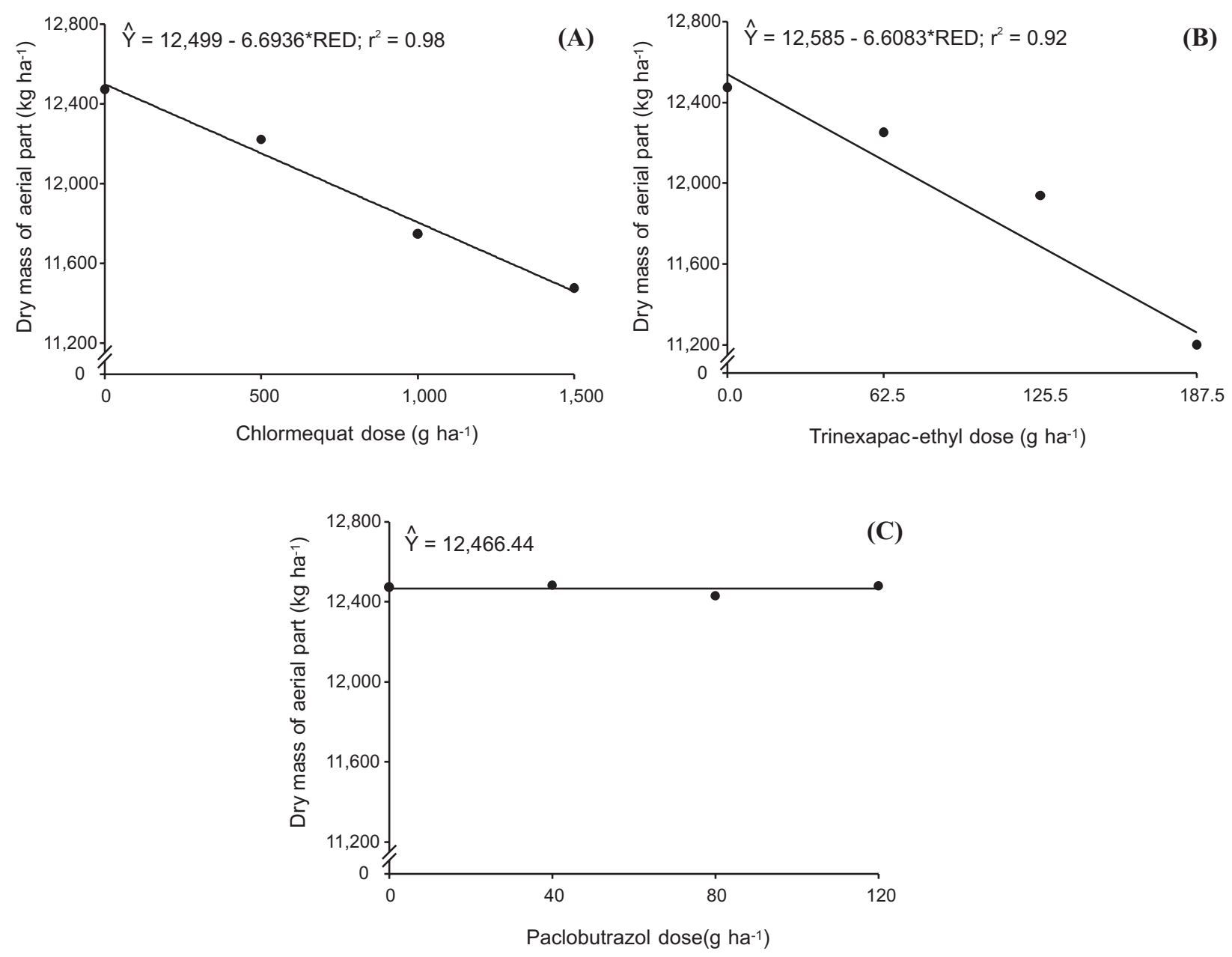

Figure 3 - Dry mass of the aerial part of Pioneiro wheat cultivar treated with growth rates of the retardants (A) chlormequat, (B) trinexapac-ethyl and (C) paclobutrazol. CV $(\%)=8.12$. Viçosa-MG, 2005

The yield of the plants treated with paclobutrazol were not significantly different from that of those treated with chlormequat, and both products gave higher yield than trinexapac-ethyl (Table 2). The lowest yield obtained with trinexapac-ethyl does not corroborate the reports of Zagonel et al. (2002a,b), who found no differences in yield with $125 \mathrm{~g} \mathrm{ha}^{-1}$ of trinexapac-ethyl, compared to the control without the growth retardant. These authors, however, only worked with a single rate of $125 \mathrm{~g} \mathrm{ha}^{-1}$ of trinexapac-ethyl, whereas in this work, rates up to $187.5 \mathrm{~g}^{\mathrm{ha}^{-1}}$ were tested. Furthermore, effects of locality and cultivars can produce differentiated responses. The results found with trinexapac-ethyl suggest that it should be used with caution, as it can cause considerable reductions in wheat yield. On the other hand, chlormequat caused no reduction in grain yield, making it more efficient than the others. However, it was less effective in reducing plant height than trinexapac-ethyl.

Wheat yield responded in a quadratic way to the increase in trinexapac-ethyl rates (Figure 4). Maximum yield $\left(5,288 \mathrm{~kg} \mathrm{ha}^{-1}\right)$ was obtained with $57.7 \mathrm{~g} \mathrm{ha}^{-1}$ of trinexapac-ethyl. Chlormequat and paclobutrazol rates had no influence on grain production. The increase in yield with rates of trinexapac-ethyl up to $57.7 \mathrm{~g} \mathrm{ha}^{-1}$ can be related to the modification of plant architecture. According to Zagonel $\&$ Fernandes (2007), the application of this retardants turn less prostrated leaves, promoting lower self-shading that culminates 

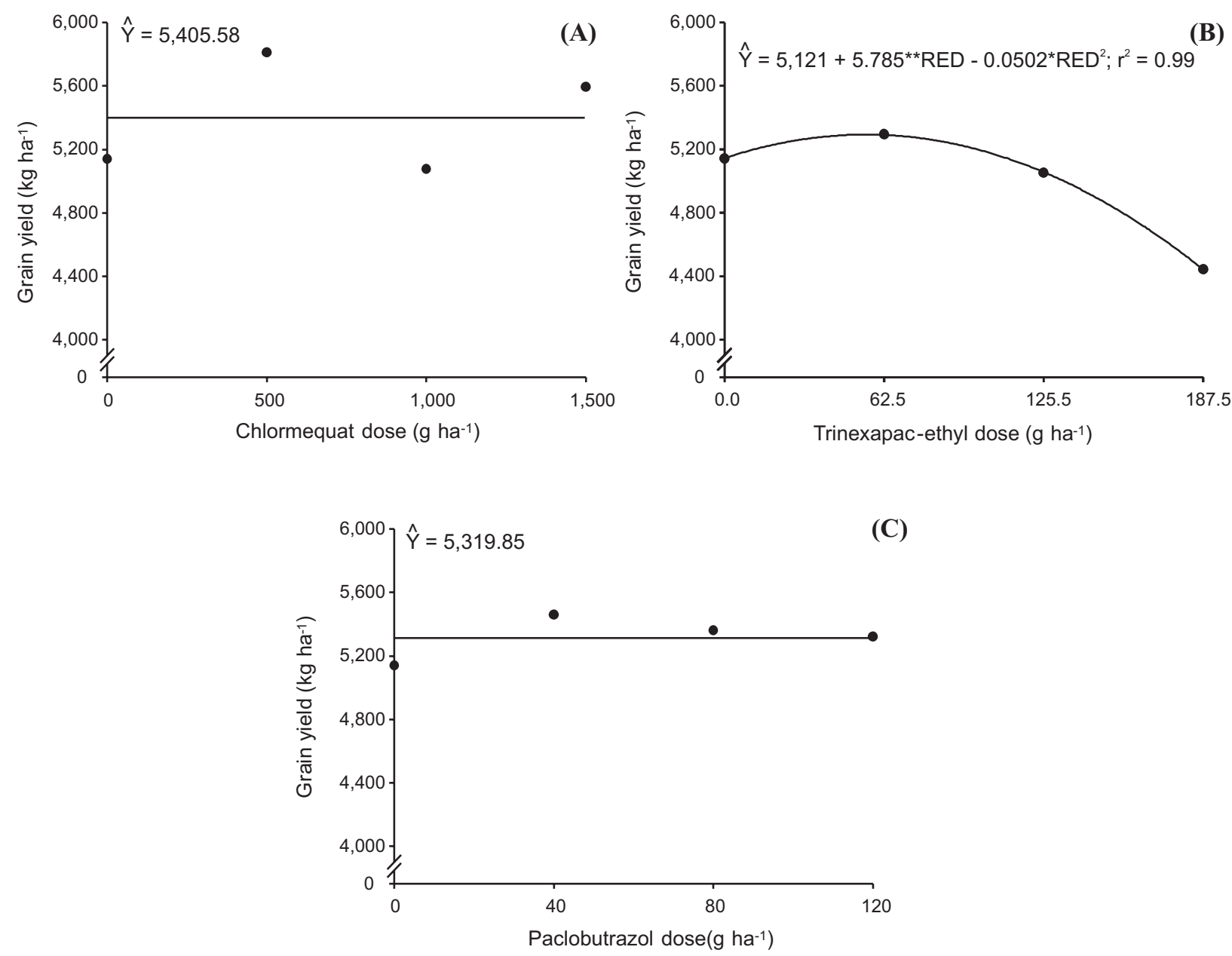

Figure 4 - Grain yield of Pioneiro wheat cultivar treated with growth rates of the retardants (A) chlormequat, (B) trinexapac-ethyl and (C) paclobutrazol. CV (\%) = 8.07. Viçosa-MG, 2005.

with increase in sunlight capture and, consequently, in photosynthetic rates. On the other hand, reduced in yield with increasing rates is the result of smallest photosynthetic area and lower stored reserves for translocation at grain filling time, as the plants showed lower dry mass. In addition, Heckman et al. (2002) reported effects of trinexapac-ethyl on the respiration of wheat plants, affecting metabolism. Quadratic responses for grain yield were also found for the cultivars OR-1, CD-104, CD-105, Alcover, Onyx, Vanguarda, Supera, CEP-24 with the rates 0, 31.2, 62.4, $93.7,125,156.2 \mathrm{~g} \mathrm{ha}^{-1}$ of trinexapac-ethyl (Zagonel \& Fernandes, 2007).

The harvest index of plants treated with trinexapac-ethyl at Time 2 was lower than at Time 1 and smaller than the plants treated with chlormequat or paclobutrazol in the same period. There were no differences among growth retardants at Time 1 (Table 2). The results with trinexapac-ethyl were similar to those reported for CD-105 cultivar, which had lower harvest index with trinexapac-ethyl applied at the stage of the second and third visible nodes than when applied at the stage of the first and second visible nodes. However, this did not occur with cultivars OR-1, CD-104, Alcover, Onyx, Vanguarda, Supera, and CEP-24 (Zagonel \& Fernandes, 2007). These results suggest that the response for this trait, among other factors, varies as a function of farming conditions, and, mainly, of the used cultivar.

Plant height reduction in wheat treated with trinexapac-ethyl is higher than with chlormequat, which, in turn is higher than 
with paclobutrazol. The action of chlormequat and paclobutrazol on plant height occurs regardless of application time but, trinexapacethyl applied at stage 8 of the Feeks and Large scale is more effective than when applied at stage 6 of the same scale. Increasing retardant rates promote reduction in plant height but only trinexapac-ethyl affects grain yield, being this a quadratic performance, with yield reduction under higher rates.

\section{ACKNOWLEDGEMENTS}

The authors would like to thank the Conselho Nacional de Desenvolvimento Científico e Tecnologico (CNPq) and the Fundação de Amparo à Pesquisa do Estado de Minas Gerais (FAPEMIG) for the grants and financial support.

\section{LITERATURE CITED}

BUZETTI, S. et al. Resposta de cultivares de arroz a doses de nitrogênio e do regulador de crescimento cloreto de clormequat. Pesq. Agropec. Bras., v. 41, n. 12, p. 1731-1737, 2006.

DUARTE FILHO, J.; ANTUNES, L. E. C.; PÁDUA, J. G. GA3 e Paclobutrazol no florescimento e na produção de frutos em duas cultivares de morangueiro. Hortic. Bras., v. 22, n. 2 , p. 202-205, 2004

EMPRESA BRASILEIRA DE PESQUISAAGROPECUÁRIA - EMBRAPA. Informações técnicas para a cultura de trigo na região do Brasil central safra -2005 e 2006. In: REUNIÃO DA COMISSÃO CENTRO BRASILEIRA DE PESQUISA DE TRIGO, 12., 2005. Goiânia. Anais... Goiânia, 2005. p. 1-82. (Documentos / Embrapa Arroz e feijão, ISSN 1516-7518; 173)

EMPRESA BRASILEIRA DE PESQUISAAGROPECUÁRIA - EMBRAPA. Centro Nacional de Pesquisa Agropecuária de Solos. Sistema brasileiro de classificação de solo. Rio de Janeiro: Embrapa Solos, 2006. 306 p.

FREITAS, F. C. L. et al. Efeitos do trinexapac-ethyl sobre o crescimento e florescimento da grama-batatais. Planta Daninha, v. 20, n. 3, p. 477-486, 2002.

FURLANI JÚNIOR, E. et al. Modos de aplicação de regulador vegetal no algodoeiro, cultivar IAC-22, em diferentes densidades populacionais e níveis de nitrogênio em cobertura. Bragantia, v. 62, n. 2, p. 227-233, 2003

GUOPING, Z. Gibberellic acid (GA3 ) modifies some growth and physiological effects of paclobutrazol (PP333) on wheat. J. Plant Growth Regul., v. 16, n. 1, p. 21-25, 1997.

HAJHASHEMI, S. et al. Exogenously applied paclobutrazol modulates growth in salt-stressed wheat plants. Plant Growth Regul., v. 53, n. 2, p. 117-128, 2007.
HECKMAN, N. L. et al. Influence of trinexapac-ethyl on respiration of isolated wheat mitochondria. Crop Sci., v. 42, p. 423-427, 2002.

KLEIN, J. D. et al. Establishment of wheat seedlings after early sowing and germination in an arid mediterranean environment. Agron. J., v. 94, 3, p. 585-593, 2002.

LAMAS, F. M.; ATAIDE, M. L.; BANZATTO, D. A Reações do algodoeiro CNPA-ITA 90 ao cloreto de mepiquat. Pesq. Agropec. Bras., v. 35, n. 3, p. 509-516, 2000.

LAMAS, F. M. Estudo comparativo entre cloreto de mepiquat e cloreto de chlormequat aplicados no algodoeiro Pesq. Agropec. Bras., v. 36, n. 2, p. 265-272, 2001.

MATEUS, G. P.; LIMA, E. V.; ROSOLEM, C. A. Perdas de cloreto de mepiquat no algodoeiro por chuva simulada. Pesq. Agropec. Bras., v. 39, n. 7, p. 631-636, 2004.

MATYSIAK, K. Influence of trinexapac-ethyl on growth and development of winter wheat. J. Plant Prot. Res., v. 46, n. 2, p. 133-143, 2006.

RODRIGUES, O. et al. Redutores de crescimento. Passo Fundo: Embrapa Trigo, 2003. 18 p html. (Embrapa Trigo. Circular Técnica, 14) Disponível em: <http://www.cnpt. embrapa.br/biblio/ci/p_ci14.htm>. Acesso em: 22 abr. 2006.

SRIVASTAVA, L. M. Plant growth and development Hormones and environment. San Diego: Academic Press, 2002. $772 \mathrm{p}$

STACHECKI, S.; PRACZYK, T.; PRACZYK, K. Adjuvant effects on plant growth regulators in winter wheat. J. Plant Prot. Res., v. 44, n. 4, p. 365-371. 2004.

STYER, R. C. Maximizing chemical growth retardants. Greenhouse Product News, v. 13, n. 3, p. 513-529, 2003

TAIZ, L.; ZEIGER, E. Fisiologia vegetal. 3.ed. Porto Alegre: Artmed, 2004. 719 p.

TINOCO, S. A. Doses e formas de aplicação dos retardantes de crescimento Clormequat, Daminozide e Paclobutrazol na cultura do gerânio (Pelargonium $x$ hortorum L.H. Bailey). 2005. 61 f. Dissertação (Mestrado em Fitotecnia) - Universidade Federal de Viçosa, Viçosa, MG, 2005.

ZAGONEL, J.; FERNANDES, E. C. Doses e épocas de aplicação do redutor de crescimento afetando cultivares de trigo em duas doses de nitrogênio. Planta Daninha, v. 25, n. 2, p. 331-339, 2007.

ZAGONEL, J.; VENANCIO. W. S.; KUNZ, R. P. Efeito de regulador de crescimento na cultura de trigo submetido a diferentes doses de nitrogênio e densidades de plantas. Planta Daninha, v. 20, n. 3, p. 471-476, 2002a.

ZAGONEL, J. et al. Doses de nitrogênio e densidades de plantas com e sem um regulador de crescimento afetando o trigo, cultivar OR-1. Ci. Rural, v. 32, n. 1, p. 25-29, 2002 b. 